\title{
KARAKTERISTIK SPERMATOZOA SAPI BALI SETELAH SEXING MENGGUNAKAN METODE KOLOM ALBUMIN DENGAN LAMA WAKTU SEXING YANG BERBEDA
}

\author{
Sunarti ${ }^{1)}$, Takdir Saili ${ }^{2)}$ dan La Ode Nafiu ${ }^{2)}$ \\ ${ }^{1)}$ Alumnus Fakultas Peternakan UHO \\ ${ }^{2)}$ Dosen Fakultas Peternakan UHO
}

\begin{abstract}
ABSTRAK
Penelitian ini menggunakan Racangan Acak Lekap (RAL) dengan tiga perlakuan dan enam ulangan. Perlakuan dalam penelitian ini adalah waktu sexing yang terdiri atas 20 menit (W1), 35 menit (W2) dan 50 menit (W3), sedangkan ulangannya adalah penampungan semen sebanyak enam kali. Parameter makroskopis yang diukur meliputi volume, warna, derajat Keasaman ( $\mathrm{pH})$, sedangkan parameter mikroskopis meliputikonsentrasi, gerakan massa, persentase motilitas, persentase spermatozoa hidup dan persentase membran plasma utuh serta non return rate.Hasil penelitian menunjukkan bahwa secara makroskopis dan mikroskopis yaitu volume $(\mathrm{ml})(5,5 \pm 0,53)$, warna (putih krem), $\mathrm{pH}(7 \pm 0,00)$, konsentrasi $(1185,57 \pm 392,09)$, persentase motilitas $(80 \pm 0.0)$, persentase spermatozoa hidup $(94,71 \pm 1,38)$ dan persentase membran plasma utuh $(96,14 \pm 1,46)$. Hasil penelitian setelah sexing kualitas spermatozoa tidak menunjukkan perbedaan pada inkubasi yang berbeda baik pada lapisan atas maupun lapisan bawah. Hasil IB menggunakan semen pasca sexing didapatkan non return rate sebesar $79 \%$. Berdasarkan hasil tersebut dapat disimpulkan kualiatas spermatozoa sapi Bali hasil sexing masih layak untuk diinseminasikan pada induk sapi untuk menghasilkan anak ternak.
\end{abstract}

Kata Kunci: Sapi Bali, spermatozoa, kolom albumin, sexing, kualitas

\begin{abstract}
The objective of this research was to evaluate characteristic and quality of bali cattle spermatozoa after sexing and to evaluate fertility of sexed spermatozoa following artificial insemination in bali cow. Randomized completely design was used with three treatments of sexing period: 20 min. (W1), $35 \mathrm{~min}$. (W2)and $50 \mathrm{~min}$. (W3) and six replications. Collecting semen was considered as replication. Parameter measured consisted of macroscopic parameter (volume, color, and $\mathrm{pH}$ ) for fresh semen, microscopic parameter (concentration, mass movement, motility, viability, and intact membrane of spermatozoa) for both fresh and after sexing, and non return rate. The results showed that fresh semen had quality as followed: volume $(5,5 \pm 0,53 \mathrm{ml})$, color (white), concentration $\left(1185,57 \pm 392,09 \times 10^{6} / \mathrm{ml}\right)$, motility $(80 \pm 0.0 \%)$, viability $(94,71 \pm 1,38 \%)$, and intact membrane $(96,14 \pm 1,46 \%)$.The quality of spermatozoa after sexing had no significant differences among treatments for both spermatozoa in upper layer or bottom later of the albumin column. While the non return rate was $79 \%$. Based on the results it was concluded that quality of spermatozoa of Bali cattle following sexing could be used in artificial insemination for producing calf.
\end{abstract}

Keywords: Bali cattle, spermatozoa, column albumin, sexing, quality 


\section{PENDAHULUAN}

$\begin{array}{r}\text { Penemuan teknologi di } \\ \text { berbagai } \\ \text { dapat }\end{array}$
dimanfaatkan untuk $\begin{array}{r}\text { daternak } \\ \text { mengatasi }\end{array}$
masalahsubsektor peternakan terutama
dalam upaya meningkatkan produktivitas
ternak.Salah satu teknologi tersebut adalah
sexing sperma.Melalui teknologi ini, kita
dapat mengontrol jenis kelamin anak ternak
yang akan diproduksi. Teknologi sexing
sangat bermanfaat bagi para peternak sapi
potong karena melalui teknik sexing mereka
dapat memproduksi lebih banyak anak
jantansesuai keinginannya. Demikian
halnyapeternak sapi perah yang lebih
menginginkan kelahiran anak betina (untuk
produksi susu) dalam suatu kelahiraan
dibandingkan anak jantan, dapat
menggunakan teknik sexing untuk
meningkatkan efisiensi usahanya.

Berbagai teknik dan metode sexing sperma telah diperkenalkan dan diterapkan pada berbagai hewan ternak, antara lain metode kolum albumin, sentrifugasi dengan gradient densitas percoll, motilitas dan pemisahan elektroforesis, isoelectric focusing, teknik manipulasi hormonal, $\mathrm{H}-\mathrm{Y}$ antigen, flow sorting, dan metode penyaringan menggunakan kolom Sephadex(Saili dkk., 2000).

Penerapkan metode kolum albumin untuk sexing sperma pada sapi $\mathrm{FH}$, telah dilakukan oleh Saili (1999). Medium sexing yang digunakan adalah campuran antara putih telur dan medium Bracket-Oliphant (BO) yang merupakan hasil modifikasi mediumBovine Serum Albumin (BSA).Metode ini mudah sekali diterapkan di lapangan karena putih telur mudah diperoleh dan harganya terjangkau. Pada penelitian tersebut kombinasi medium pemisah yang digunakan adalah konsentrasi 10 persen albumin telur pada lapisan atas dan 30 persen pada lapisan bawah, dan hasilnyamenunjukkan konsentrasi albumin 10 persen dan 30 persen mampu mengubah proporsi perolehan spermatozoa dari kondisi alamiah.
Upaya memodifikasi medium sexing terus dilakukan untuk mendapatkan kualitas dan kuantitas sperma yang memenuhi syarat untuk digunakan pada program IB. Penggunaan konsentrasi medium albumensebagai medium sexing dan lama waktu sexing yang tepat diprediksi akan dapat memberikan hasil sexing yang optimal. Sexing sperma sapi Bali khususnya di Sulawesi Tenggara belum pernah dilakukan. Demikian halnya dengan informasi tentang pemanfaatan spermatozoa hasil sexing juga belum pernah dilakukan, oleh karena itu perlu dilakukan penelitian untuk mengetahui karakteristik spermatozoa sapi Bali baik sebelum maupun sesudah proses sexing.

\section{METODE PENELITIAN}

Penelitian ini dilaksanakan di Laboratorium, di Unit Pelayanan Teknis Daerah Peternakan Sulawesi Tenggara di Desa Morome, Kecamatan Konda, Kabupaten Konawe Selatan, Sulawesi Tenggara. Penelitian ini akandilaksanakan pada bulan Maret 2015 sampai Mei 2015.

Materi yang digunakan adalah semen sapi yang diperolehsecara teratur dari pejantan sapi bali yang berumur 3 tahun dengan bobot badan lebih kurang 350 kg.Pakansapi berupa rumput lapangan $\pm 10 \%$ dari berat badan dan makanan penguat (konsentrat) sebanyak $4-5 \mathrm{~kg}$ per ekor per hari.

Materi utama medium sexing yang digunakan adalah bagian cair dari putih telur (albumen), dan sebagai pelarutnya digunakan medium modifikasiBrackettOliphant (m-BO) (Saili, 2014). Medium tersebut juga digunakan sebagai medium pencuci semen baik sebelum proses sexingmaupun setelah proses sexing dan sebagai medium penambah volume semen dalam upayamendapatkan konsentrasi spermatozoa yang ideal pada proses sexing. Selain itu, juga dibutuhkan pelarut semen Tris-Kuning telur yang digunakan pada saat menyimpan semen cair setelah proses sexing. 
Peralatan yang digunakan pada penelitian ini adalah seperangkat alat vagina buatan yang digunakan untuk menampung semen. Tabung yang digunakan pada proses sexing spermatozoa adalah tabung reaksi dengan diameter $1 \mathrm{~cm}$ dan tinggil0 $\mathrm{cm}$. Untuk membuat dan menyimpan medium digunakan gelas ukur, gelas erlemeyer dan gelas beaker dalam berbagai ukuran. Glass penutup dan glass obyek digunakan untuk membuat preparat spermatozoa bagi berbagai keperluan pengamatan. Haemocytometer dan sentrifus (CentraMP4RModel, International Equipment Company, USA) masing-masing digunakan sebagai alat untuk menghitung konsentrasi spermatozoa dan membersihkan spermatozoa. Selain itu juga, digunakan water bath, magnetik stirer, stopwatch, corong karet,tabung gelas penampung berskala, pipet Pasteur,mikroskop, $\mathrm{pH}$ indicator paper, pemanas bunsen, timbangan elektronik,rak tabung, counter, dan lain-lain. Penelitian ini menggunakan Racangan Acak Lekap (RAL) dengan tiga perlakuan dan enam ulangan. Perlakuan dalam penelitian ini adalah waktu sexing yang terdiri atas 20 menit (W1), 35 menit (W2) dan 50 menit (W3), sedangkan ulangannya adalah penampungan semen sebanyak enam kali.

Penampungan semen dilakukan dengan menggunakan vagina buatan yang terbuat dari rangkaian tabung karet yang berlubang pentil, karet inner liner, karet pengikat, corong karet, dan tabung penampung berskala.Air panas $\left(40-52^{\circ} \mathrm{C}\right)$ dimasukkan ke dalam vagina buatan melalui lubang pentil hingga mencapai setengah bagian, kemudian lubang pentil ditutup dan dipompa.Kekenyalan vagina buatan diukur dengan jari jika dirasakan cukup, karet bagian luar vagina buatan diberi vaselin hingga $1 / 3$ bagian panjangnya.Sapi betina pemancing (teaser) dimasukkan ke dalam service create, selanjutnya sapi pejantan dibiarkan mendekati sapi betina pemancing beberapa kali untuk meningkatkan libido dan setelah sapi pejantan menaiki pemancing, bagian preputium dipegang, ujung penis diarahkan ke lubang vagina buatan dengan posisi miring. Semen yang tertampung segera dievaluasi secara makroskopis dan mikroskopis.

Metode pemisahan menurut Saili (1999),yaitu semen sapi yang ditampung (ejakulat)dicuci dengan penambahan medium Mbo dan disentrifugasi padakecepatan $3000 \mathrm{rpm}$ selama 10 menit. MediummBO ditambahkan kembali pada endapansemen sampai konsentrasi menjadi 150 juta selper mililiter. Satu mililiter sampel dimasukkanke dalam tabung yang telah terisi medium sexing $10 \%$ dan $30 \%$, kemudiandibiarkan selama 20 menit, 35 menit, dan 50 menit sesuai perlakuan pada suhu kamar.Fraksi semen bagian atas selanjutnya dipisahkan dari fraksisemen bagian bawah dengan menyedotmasingmasing fraksi menggunakan pipet danditampung dalam tabung centrifuge, kemudianditambahkan medium $\mathrm{mBO}$ sebelum dicuci cara dengansentrifugasi pada kecepatan 3000 rpm selama10 menit.

Variabel yang diukur pada penelitian ini adalah kualitas semen segar dan kualitas spermatozoa sebelum dan sesudah sexing yang meliputipengamatan secara makroskopis dan mikroskopis. Pengamatan kualitas semen secara makroskopis terdiri atas :

1. Volume

Volume sapi yang dihasilkan oleh seekor sapi jantan dalam satu ejakulasi sangat bervariasi. Hal ini dipengaruhi, antara lain oleh umur sapi, besar tubuh, status kesehatan, status reproduksi, kualitas makanan, dan frekuensi penampungan. Selain itu, teknik dan metode penampungan serta persiapan alat penampungan akan mempengaruhi volume semen yang dihasilkan (Saili, 1999).

2. Warna

Warna semen dapat dijadikan indikator untuk memprediksi kosentrasi spermatozoa yang berada di dalam semen secara cepat. Warna pada semen dapat 
diamati secara visual setelahpenampungan, semen yang baik adalah krem

3. Derajat Keasaman $(\mathrm{pH})$

Derajat Keasaman (pH)diukur dengan cara mengambil sedikit semensegar menggunakan ose dan diletakkan padakertas lakmus, selanjutnya dilihat $\mathrm{pH}$ semendengan menggunakan $\mathrm{pH}$ indicator paper, pH normalsemen 6,4-7,8 (Garner dan Hafez, 2008). pH sangat menentukan status kehidupan spermatozoa di dalam semen.

Sedangkan evaluasi kualitas spermatozoa secara mikroskopis baik sebelum maupun sesudah sexing terdiri atas

\section{Konsentrasi}

Evaluasi terhadap konsentrasi dilakukan dengan menggunakan pipet haemocytometer dan kamar hitung Neubauer. Semen diisap sampai skala 0,5 kemudian ditambah dengan larutan $\mathrm{NaCl}$ $3 \%$ dan diisap sampai mencapai angka 1,01. Larutan dalam pipet digoyang-goyang membentuk angka delapan selama2-3 menit agar larutan homogen, selanjutnya larutan tersebut dibuang beberapa tetes. Setelah itu semen diteteskan pada kamar hitung Neubauer yang ditutup dengan gelas penutup, kemudian diamati dengan mikroskop cahaya pembesaran 400x. Menghitung spermatozoa yang terdapat di dalam lima kotak dengan arah diagonal. Hasil perhitungan konsentrasi spermatozoa dalam jumlah kamar yang dihitung lima kotak dengan 80 ruangan kecil di dalamnya dikalikan 107 per milliliter (Susilawati, 2011).

2. Gerakan massa

Gerakan massa diamati dengan menggunakanmikroskop cahaya. Semen diletakkan di atasgelas objek tanpa cover glass dengan perbesaran100×. Kriteria penilaian massa spermatozoasangat baik $(+++)$ terlihat adanya gelombangbesar, banyak, gelap, tebal dan aktif bergerak.Baik $(++)$ terdapat gelombang-gelombangkecil tipis, jarang, kurang jelas dan bergeraklamban. Cukup (+), bila tidak terlihat gelombang melainkan gerakan - gerakan individual aktif progresif dan buruk (-) , bila tidak ada gerakan sama sekali (Susilawati,2011).

3. Persentase motilitas

Persentase motilitas dapat dipengaruhi serangkaian perlakuan mulai proses pencucian hingga proses pemisahan spermatozoa. Proses pencucian yang berakibat pada pengurangan kosentrasi plasma semen dan menggantikannya dengan BO mungkin merupakan salah satu faktor yang menyebabkan menurunnya nilai motilitas spermatozoa, bila dihubungkan dengan ketersediaan sumber energi bagi spermatozoa, walaupun di dalam medium BO itu sendiri terdapat glukosa (Saili, 1999).

4. Persentase membran plasma utuh.

Untuk mengetahui keutuhan membran plasma spermatozoa sapi yang sangat erat kaitannya dengan kondisi hidup-mati spermatozoa digunakan prosedur Hypoosmotic Swelling Test (HOS-Test) (Correa dan Zavos, 1994). Sampel semen dimasukkan kedalam larutan hipo-osmotik $0,032 \mathrm{M} \quad \mathrm{NaCl}$ $(0,179 \mathrm{~g} \mathrm{NaCl}$ dalam $100 \mathrm{ml}$ akuabides $)$, kemudian diinkubasi selama satu jam pada suhu $37^{\circ} \mathrm{C}$. Spermatozoa dengan membran plasma utuh ditandai dengan ekor yang melingkar. Evaluasi dilakukan dengan menggunakan mikroskop pembesaran 10 x 40, sedangkan jumlah minimal sampel spermatozoa yang diamati adalah 100 spermatozoa (Saili, 1999).

\section{HASIL DAN PEMBAHASAN}

\section{A. Kualitas Semen Segar Sapi Bali}

Kualitas semen dan spermatozoa sapi Bali yang dievaluasi meliputi kualitas makroskopis (volume, warna dan $\mathrm{pH}$ ) dan mikroskopis (konsentrasi, persentase motilitas, persentase spermatozoa hidup dan persentase membran plasma utuh).Data selengkapnya disajikan pada Tabel 1 . 
Tabel 1. Rataan Kualitas Semen dan Spermatozoa Segar Sapi Bali

\begin{tabular}{lc}
\hline \multicolumn{1}{c}{ Variabel } & Nilai \\
\hline Volume $(\mathrm{ml})$ & $5,5 \pm 0,53$ \\
Warna & Putih krem \\
$\mathrm{pH}$ & $7 \pm 0,00$ \\
Konsentrasi $\left(\times 10^{6} / \mathrm{ml}\right)$ & $1185,57 \pm 392,09$ \\
Persentase Motilitas $(\%)$ & $80 \pm 0.0$ \\
Persentase Spermatozoa Hidup (\%) & $94,71 \pm 1,38$ \\
Persentase Membran Plasma Utuh $(\%)$ & $96,14 \pm 1,46$ \\
\hline
\end{tabular}

Data pada Tabel 1 menunjukkan bahwa rataan volume semen segar sapi Bali yang diperoleh pada penelitian ini adalah $5,5 \pm 0,53 \mathrm{ml}$. Volume semen sapi yang diperoleh masih dalam kisaran normal sesuai pendapat Toelihere (1985) yang menyatakan bahwa volume semen sapi bervariasi antara 1-15 ml.Adanya perbedaan volume semen setiap ejakulasi disebabkan oleh perbedaan bangsa, umur, ukuran badan, pakan, frekuensi penampungan dan berbagai faktor lain.

Volume semen sapi Bali yang diperoleh pada penelitian ini sedikit lebih tinggi dibandingkan dengan hasil penelitian Nursalmah (2014) yang menyatakan bahwa rataan volume semen segar sapi Bali yakni sebesar 5,26 $\pm 0,99 \mathrm{ml}$. Demikian halnya dengan hasil penelitian Ratnawati dkk. (2008) yang hanya memperoleh rataan volume semen segar sapi bali sebanyak 4,5 $\pm 2,3 \mathrm{ml}$. Toelihere (1993) menyatakan bahwa volume semen yang dihasilkan seekor pejantan sapi dalam satu ejakulasi cukup bervariasi dan sangat tergantung dari umur, berat, status kesehatan, dan reproduksi, kualitas makanan, frekuensi penampungan dan bangsa sapi.

\section{B. Warna Semen}

Warna semen umumnya dijadikan indikator untuk memprediksi konsentrasi spermatozoa yang terdapat dalam semen secara cepat. Hasil pemeriksaan makroskopis menunjukkan bahwa semen segar pada penelitian ini berwarna putih krem. Hal ini berarti bahwa semen tersebut normal, sesuai pendapat Feradis (2010) dan Nursyam (2007) bahwa semen sapi normal berwarna putih susu atau krem keputihan dan keruh. Menurut Gardner dan Hafez (2008), rata-rata warna semen adalah putih kekuningan atau krem.Jika semen berwarna hijau kekuning-kuningan berarti semen mengandung kuman Pseudomonas aeruginosa, sedangkan semen yang berwarna merah berarti mengandung darah dan semen yang berwarna coklat berarti semen tersebut mengandung darah yang telah membusuk. Warna semen pada penelitian ini sama dengan warna semen yang dilaporkan oleh Nursalamah (2014) dan Ratnawati dkk. (2008) pada sapi bali yaitu berwarna putih kekuningan (krem).

\section{Derajat Keasaman (pH) Semen}

Derajat keasaman $(\mathrm{pH})$ semen merupakan salah satu faktor pembatas kelangsungan hidup spermatozoa di dalam semen.Perubahan $\mathrm{pH}$ ke arah yang lebih asam (angka lebih kecil dari 7) akibat penimbunan asam laktat hasil metabolisme anaerob dapat menurunkan tingkat kelangsungan hidup spermatozoa (Toelihere, 1993). Derajat keasaman $(\mathrm{pH})$ semen sapi Bali yang diperoleh pada penelitian ini masih berkisar pada $\mathrm{pH}$ normal, yaitu 7,00 $\pm 0,00$. Feradis (2011) menyatakan bahwa setiap bangsa sapi mempunyai nilai $\mathrm{pH}$ semen segar yang berbeda-beda. Beberapa hasil penelitian menyatakan $\mathrm{pH}$ semen yang berbeda-beda tetapi masih dalam kisaran yang normal, seperti Butar (2009) menyatakan bahwa semen segar mempunyai $\mathrm{pH}$ antara 6,4-7,8, Nursyam (2007) melaporkan bahwa pH semen yang berkualitas baik adalah 6,8-6,7. Nursalamah(2014) melaporkan bahwa $\mathrm{pH}$ semen sapi yang segar berkisar $6,8 \pm 0,45$, Ratnawati dkk. (2008) memperoleh nilai pH 
semen segar sebesar 6,5, sedangkan Gardner dan Hafez (2008) menyatakan bahwa rata-rata $\mathrm{pH}$ semen sapi yang normal adalah 6,4-7,8.

\section{Konsentrasi Spermatozoa}

Konsentrasi spermatozoa yang diperoleh pada penelitian ini sebesar $1185,57 \pm 392,09 \times 10^{6} / \mathrm{ml}$. Konsentrasi tersebut masih tergolong normal karena menurut Gardner dan Hafez (2000) konsentrasi spermatozoa sapi berkisar antara $800 \times 10^{6}-2000 \times 10^{6} / \mathrm{ml}$. Akan tetapi, hasil penelitian ini agak berbeda dibanding hasil penelitian yang dilakukan oleh Ratnawati (2008) pada sapi Bali yang melaporkan bahwa konsentrasi spermatozoa semen segar sapi bali sebesar 1309,3 $\pm 21,4$ x $10^{6} / \mathrm{ml}$.

\section{E. Persentase Motilitas Spermatozoa}

Persentase motilitas spermatozoa merupakan salah satu indikator utama dalam proses evaluasi spermatozoa. Variabel ini sangat erat hubungannya dengan daya fertilisasi spermatozoa. Nilai rata-rata persentase motilitas spermatozoa sapi bali yang digunakan pada penelitian ini adalah $80 \pm 0,0 \%$. Nilai ini masih pada kisaran persentase motilitas spermatozoa yang layak digunakan untuk fertilisasi, baik secara in vivo dan maupun in vitro. Pada umumnya dan yang terbaik adalah pergerakan progresif atau gerakan aktif maju ke depan. Hasil penelitian ini jauh berbeda dengan penelitian Rahmah (2007) yang memperlihatkan motilitas individu $71,75 \%$, dan penelitian Nursalamah (2014) yang mendapatkan persentase motilitas sebesar $68 \% \pm 8,37$.

\section{F. Persentase Spermatozoa Hidup}

Persentase spermatozoa hidup yang diperoleh pada penelitian ini adalah $94,71 \pm 1,38 \%$. Nilai ini masih termasuk dalam kisaran normal dan tidak jauh berbeda dengan hasil penelitian Pratiwi dkk. (2006) yaitu 93,5\% 2,1 . Persentase spermatozoa hidup yang sama juga dilaporkan oleh Pamungkas dkk. (2006) yaitu sebesar $93,5 \pm 2,1 \%$.

\section{G. Persentase Membran Plasma Utuh (MPU)}

Keutuhan membran plasma bagi spermatozoa mutlak diperlukan untuk memenuhi fungsinya sebagai pelindung organel di dalam sel dan penyaring bagi pertukaran zat intraseluler dan ekstraseluler. Rataan persentase membran plasma utuh spermatozoa yang diperoleh pada penelitian ini adalah 96,14 $\pm 1,46 \%$. Persentase spermatozoa yang mempunyai plasma membrane utuh yang diperoleh pada penelitian ini masih dalam kisaran normal jika dihubungkan dengan kemampuan fertilisasi seperti yang dikemukakan oleh Revell dan Mrode (1994) bahwa nilai persentase keutuhan membran plasma yang kurang dari $60 \%$ dikategorikan sebagai spermatozoa yang infertil dan tidak memenuhi syarat untuk diproses lebih lanjut. Saili dkk.(2000) menyatakan bahwa salah satu kriteria kualitas spermatozoa yang baik adalah apabila memiliki nilai persentase keutuhan membrane lebih dari $80 \%$.

\section{H. Kualitas Spermatozoa Sapi Bali Setelah Sexing}

Sebelum proses sexing dilakukan, konsentrasi awal spermatozoa harus ditentukan agar secara teknis semen tetap berada di lapisan atas kolom sexing. Berdasarkan hasil uji coba diperoleh bahwa pengenceran semen sampai dengan konsentrasi 200 juta per mili liter masih memenuhi syarat secara teknis untuk digunakan pada proses sexing (Saili, 2000).

Proses sexing spermatozoa berlangsung selama 20 menit, 35 menit dan 50 menit (sesuai perlakuan).Hal ini dimaksudkan untuk mengetahui waktu yang paling efektif dalam upaya memperoleh konsentrasi spermatozoa yang tinggi dengan motilitas yang masih tetap terjaga pada kisaran motilitas yang dipersyaratkan untuk pengelolaan semen cair atau semen beku. 


\section{Konsentrasi Spermatozoa Sapi Bali Setelah Sexing}

Konsentrasi spermatozoa setelah sexing diperoleh dari dua bagian yaitu spermatozoa pada lapisan atas (medium albumen 10\%) dan spermatozoa pada lapisan bawah (medium albumen 30\%). Pada saat sexing, semen sebanyak $1 \mathrm{ml}$ dengan konsentrasi $200 \mathrm{juta} / \mathrm{ml}$ diletakkan Tabel 2. Rataan Konsentrasi Spermatozoa Sapi Bali Setelah Sexing

\begin{tabular}{ccc}
\hline \multirow{2}{*}{ Perlakuan } & \multicolumn{2}{c}{ Lapisan } \\
\cline { 2 - 3 } & Atas & Bawah \\
\hline 20 & $130,29 \pm 10,11$ & $71,43 \pm 25,58$ \\
35 & $125,43 \pm 2,51$ & $68,57 \pm 24,63$ \\
50 & $121,29 \pm 4,61$ & $65,00 \pm 23,43$ \\
\hline
\end{tabular}

Tabel 2 menunjukkan bahwa, rataan nilai konsentrasi spermatozoa sapi Bali setelah sexing pada lapisan atas pada inkubasi 20 menit, 35 menit, dan 50 menit adalah berturut-turut $130,29 \pm 10,11 \%$, $125,43 \pm 2,51 \%$ dan $121,29 \pm 4,61 \%$, sementara nilai pada lapisan bawah pada inkubasi 20 menit, 35 menit dan 50 menit berturut-turut yaitu $71,43 \pm 25,58 \%$, $68,57 \pm 24,63 \%$, dan $65 \pm 23,43 \%$.

Data pada Tabel 5 menunjukkan bahwa lapisan atas pada inkubasi 20, 35 dan 50 menit tidak ada yang berbeda nyata $(\mathrm{P}>0,05)$. Begitu pula di lapisan bawah pada inkubasi 20, 35 dan 50 menit tidak ada yang berbeda nyata $(\mathrm{P}>0,05)$. Konsentrasi pada lapisan atas pada inkubasi 20 menit lebih tinggi dari pada inkubasi 35 menit dan inkubasi 50 menit lebih rendah dari pada inkubasi 20 menit dan 35 menit, sedangkan konsentarsi lapisan bawah pada inkubasi 20 menit lebih rendah dari 35 menit namun pada inkubasi 50 menit lebih tinggi dari pada inkubasi 35 dan 20 menit. Nilai konsentrasi spermatozoa pada lapisan atas terjadi kecenderungan penurunan begitu pula pada lapisan bawah. Hal ini diduga karena perbedaan motilitas spermatozoa yang meyebabkan menyebabkan ketidaksamaan distribusi spermatozoa.

Konsentrasi spermatozoa sapi Bali hasil sexing menunjukkan bahwa gradien gradien albumin mampu mempertahankkan konsentrasi spermatozoa sapi Bali.Hal ini Tabel 3. Rataan Persentase Motilitas SpermatozoaSapi Bali Setelah Sexing (\%) pada lapisan atas kolom dan dibiarkan bergerak ke lapisan albumen baik lapisan atas maupun lapisan bawah. Setelah proses sexing selama masih-masing 20, 35 dan 50 menit maka diperoleh hasil hitungan konsentrasi spermatozoa pada masingmasing lapisan albumen seperti tertera pada Tabel sesuai dengan penelitian Ervandi et al,(2013) yang menyatakan bahwa konsentrasi spermatozoa pada lapisan atas $(\mathrm{X})$ lebih tinggi dibandingkan dengan konsentrasi spermatozoa pada lapisan bawah (Y).Hasil penelitian ini jauh berbeda dengan hasil penelitian Sianturi et al. (2004), sexingmenggunakan pengencer trissitrat buferditambah kuning telur menghasilkan konsentrasi spermatozoa pada lapisan atas dan lapisan bawah masing-masing sebesar $640,5 \pm 331,2 \quad(106 / \mathrm{ml})$ dan $522,2 \pm 312,9$ $(106 / \mathrm{ml})$.

\section{J. Rataan Persentase Motilitas}

Spermatozoa Sapi Bali Setelah Sexing

Pada lapisan atas, perlakuan lama waktu sexing 20 menit memiliki nilai persentase motilitas spermatozoa yang lebih tinggi $68,50 \pm 24,72 \%$, dibanding dengan lapisan atas pada perlakuan lama waktu sexing 35 menit dengan nilai persentase motilitas sebesar $66,25 \pm 23,57 \%$, sedangkan nilai persentase motilitas terendah didapatkan pada perlakuan lama waktu sexing 50 menit dengan persentase $65,00 \pm 23,19 \%$. Pada lapisan bawah, perlakuan lama waktu sexing 20 menit memiliki nilai persentase motilitas sebesar $60,27 \pm 1,15 \%$ disusul lama waktu sexing 35 menit sebesar $60,00 \pm 21,31 \%$ dan nilai terendah ditunjukkan oleh perlakuan lama waktu sexing 50 menit dengan nilai persentase $52,50 \pm 21,21 \%$. 


\begin{tabular}{ccc}
\hline \multirow{2}{*}{ Perlakuan } & \multicolumn{2}{c}{ Lapisan } \\
\cline { 2 - 3 } & Atas & Bawah \\
\hline 20 & $68,50 \pm 24,72$ & $60,27 \pm 1,15$ \\
35 & $66,25 \pm 23,57$ & $60,00 \pm 21,31$ \\
50 & $65,00 \pm 23,19$ & $52,50 \pm 21,21$ \\
\hline
\end{tabular}

Keterangan: Data pengamatan Diolah (2016).

Data pada Tabel 3 menunjukkan bahwa perlakuan tidak berpengaruh nyata terhadap motilitas spermatozoa pada lapisan bawah $(\mathrm{P}>0.05)$.tetapi tidak berpengaruh terhadap motilitas spermatozoa pada lapisan atas.Secara umum dapat dikatakan bahwa semakin lama waktu sexing maka persentase motilitas spermatozoa semakin menurun. Hal ini sangat logis terjadi karena semakin lama spermatozoa bergerak akan semakin banyak energi yang dibutuhkan sehingga pada akhirnya akan mengurangi kemampuannya bergerak.

Hasil penelitian ini masih lebih baik dari hasil penelitian Susilawati (2002) yang melaporkan bahwa motilitas spermatozoa hasil sexing menggunakan medium albumin putih telur dan pengencer Tris aminomethan kuning telur menghasilkan motilitas spermatozoa $50,5 \%$ pada lapisan atas dan $41 \%$ pada lapisan bawah. Menurunnya persentase spermatozoa diduga karena semakin lamanya proses inkubasi sehingga membuat spermatozoa bergerak lebih lama dan membutuhkan energi lebih banyak untuk menembus albumin telur. Spermatozoa yang banyak menggunakan energi maka akan menurun pula nilai persentase motilitasnya bahkan tidak bergerak sama sekali (Saili, 1999).

Hasil yang didapatkan pada persentase motilitas spermatozoa sapi Bali setelah sexing pada lapisan atas memiliki rataan yang lebih tinggi dari pada rataan di lapisan bawah hal ini disebabkan kesulitan bergerak spermatozoa melewati albumin putih telur di lapisan bawah. Menurut (Putra et al., 2012) mengatakan bahwa semakin tinggi konsentrasi albumin putih telur menyebabkan viskositas larutan meningkat yang menyebabkan gerak spermatozoa

Tabel 4. Rataan Persentase Spermatozoa Hidup Sapi Bali Setelah Sexing (\%) terhambat dan membutuhkan tenaga ekstra untuk menembus gradien yang berisi konsentrasi albumin putih telur.

\section{K. Rataan Persentase Spermatozoa Hidup Sapi Bali Setelah Sexing}

Rataan persentase spermatozoa hidup setelah proses sexing menggunakan gradien densitas albumin putih telur disajikan pada Tabel 4

Data pada Tabel 4 menunjukkan bahwa perlakuan lama sexing tidak berpengaruh $(\mathrm{P}>0.05)$ terhadap persentase spermatozoa hidup baik pada spermatozoa pada lapisan atas maupun pada lapisan bawah.Nilai rataan persentase spermatozoa hidup lapisan atas semakin lama semakin rendah yaitu pada inkubasi 20 menit memiliki nilai persentase $83,50 \pm 29,68 \%$, inkubasi 35 memiliki nilai persentase $81,25 \pm 28,74 \%$ dan inkubasi 50 menit memiliki nilai persentase $81,01 \pm 2,26 \%$. Begitu juga dengan rataan persentase spermatozoa hidup lapisan bawah semakin lama semakin rendah yaitu pada lama waktu sexing 20 menit memiliki nilai persentase $76,88 \pm 1,83$, lama waktu sexing 35 menit memiliki nilai persentase $73,38 \pm 25,98 \%$ dan lama waktu sexing 50 menit memiliki nilai persentase $72,14 \pm 25,56 \%$.

Perlakuan 


\begin{tabular}{ccc}
\hline & Atas & Bawah \\
\hline 20 & $83,50 \pm 29,68$ & $76,88 \pm 1,83$ \\
35 & $81,25 \pm 28,74$ & $73,38 \pm 25,98$ \\
50 & $81,01 \pm 2,26$ & $72,14 \pm 25.56$ \\
\hline
\end{tabular}

Hasil penelitian ini lebih kecil dibanding penelitian sexing menggunakan pengencer andromed menghasilkan persentase spermatozoa hidup pada lapisan atas dan lapisan bawah masing-masing adalah $91,91 \pm 3,88 \%$ dan $92,12 \pm 1,78 \%$. Kondisi ini sama seperti pengencer CEP-2 ditambah kuning telur $10 \%$ pada lapisan atas dan lapisan bawah yakni masingmasing adalah 93,3 $\pm 4,03$ dan 92,9 $\pm 2,04 \%$ (Purwoistri dkk., 2013). Hasil penelitian ini masih dikatakan normal seperti hasil penelitian Pratiwi dkk. (2006) bahwa sexing menggunakan pengencer Trisaminomethane kuning telur menghasilkan persentase spermatozoa hidup pada lapisan atas $85 \%$ dan lapisan bawah $84,7 \%$ sedangkan dalam penelitian ini masih dalam kisaran di atas $>80 \%$. Keadaan ini diduga karena pengencer CEP2 ditambah kuning telur 10\% mampu menyediakan lingkungan yang optimal bagi spermatozoa dan melindungi membran sehingga permeabilitas membran tetap normal dan tidak rusak.Pengencer CEP-2 mengandung sorbitol, yang berperan meningkatkan osmolaritas media pengencer dan sebagai sumber energi cadangan yang baik layaknya cauda epididimis sapi, yang mampu menyimpan spermatozoa selama 45 hari (Verberckmoes et al., 2004).

\section{Rataan Persentase Membran Plasma Utuh (MPU) Spermatozoa Sapi Bali Setelah Sexing}

Rataan persentase MPUspermatozoa sapi Bali setelah sexing menggunakan gradien densitas albumin putih telur disajikan pada Tabel 5.Data pada Tabel 5 menunjukkan bahwa lapisan atas dan bawah pada persentase MPU spermatozoa sapi bali setelah sexing pada masing-masing lama waktu sexing 20 menit, 35 menit, dan 50 menit tidak berpengaruh nyata $(\mathrm{P}>0,05)$.

Tabel5. Rataan Persentase MPU Spermatozoa Setelah Sexing (\%)

\begin{tabular}{ccc}
\hline \multirow{2}{*}{ Perlakuan } & \multicolumn{2}{c}{ Lapisan } \\
\cline { 2 - 3 } & Atas & Bawah \\
\hline 20 & $81,63 \pm 28,93$ & $74,50 \pm 26,43$ \\
35 & $81,14 \pm 28,77$ & $72,43 \pm 25,90$ \\
50 & $80,57 \pm 28,91$ & $70,00 \pm 24,79$ \\
\hline
\end{tabular}

Keterangan: Data pengamatan Diolah (2016).

Nilai rataan persentase MPU lapisan atas makin rendah yaitu inkubasi 20 menit memiliki nilai persentase $81,14 \pm 28,77 \%$, inkumasi 35 menit memiliki nilai persentase $81,14 \pm 28,77 \%$ sedangkan nilai terendah didapatkan pada lama inkubasi 50 menit yaitu $80,57 \pm 28,91 \%$. Sedangkan pada lapisan bawah memiliki nilai rataan persentase MPU yang semakin lama semakin tinggi yaitu pada lama waktu sexing 20 menit memiliki nilai persentase $74,50 \pm 26,43 \%$, lama waktu sexing 35 menit memiliki nilai persentase $72,43 \pm 25,90 \%$ sedangkan nilai terendah didapatkan pada lama waktu sexing 50 menit yaitu $70,00 \pm 24,79 \%$.

Menurut Aireset al., (2003), kuning telur mengandung substansi protektif berupa lesitin dan lipoprotein (Aku et al., 2007). Lesitin dan lipoprotein di dalam kuning telur memilikimolekul-molekul besar yang tidak dapat menembus membran sel spermatozoa dan berfungsi untuk melindungi dan mempertahankan integritas lipoprotein penyusun membran spermatozoa (Susilawati, 2002). 


\section{Hasil Inseminasi Buatan}

Persentase non return rate (NRR) sapi sperma hasil sexing dalam observasi 21 hari disajikan pada Tabel 6

Bali setelah diinseminasi buatan dengan

Tabel. 6 Persentase NonReturn RateSapi Bali Setelah Diinseminasi Buatan DenganSperma Hasil Sexing Dalam Observasi 21 Hari (\%)

\begin{tabular}{cccccccc}
\hline \multirow{2}{*}{$\begin{array}{c}\text { Umur } \\
\text { Sapi } \\
\text { (tahun) }\end{array}$} & $\begin{array}{c}\text { Jml } \\
\text { sapi } \\
\text { (ekor) }\end{array}$ & $\begin{array}{c}\text { Sapi yg } \\
\text { estrus } \\
\text { (ekor) }\end{array}$ & $\begin{array}{c}\text { EPPG } \\
\text { (jam) }\end{array}$ & $\begin{array}{c}\text { Kualitas } \\
\text { estrus } \\
\text { (skor) }\end{array}$ & $\begin{array}{c}\text { Sapi yg } \\
\text { di- IB } \\
\text { (ekor) }\end{array}$ & $\begin{array}{c}\text { MKK } \\
\text { (ekor) }\end{array}$ & $\begin{array}{c}\text { NRR } \\
(\%)\end{array}$ \\
\hline $3.0-4.9$ & 32 & 17 & 72.68 & 2.4 & 32 & 4 & 88 \\
$5.0-6.9$ & 20 & 15 & 68.32 & 2.5 & 20 & 3 & 85 \\
$\geq 7$ & 11 & 7 & 73.22 & 2.6 & 11 & 4 & 64 \\
\hline Jumlah & 63 & 39 & & & 63 & 11 & \\
\hline Rataan & & & 71 & 2.5 & & & 79 \\
\hline
\end{tabular}

Keterangan:

EPPG = estrus post PG (prostaglandin), lama waktu munculnya estrus setelah penyuntikan hormon prostaglandin

MKK = Minta kawin kembali, jumlah sapi yang minta kawin kembali dalam waktu 21 hari setelah di IB

$\mathrm{NRR}=$ Non return rate, persentase sapi yang tidak minta kawin lagi dalam waktu 21 setelah di IB

Jumlah sapi yang menjadi resipien pada penelitian ini adalah 63 ekor yang dibagi ke dalam tiga kelompok umur, yaitu 3.0 - 4.9 tahun (32 ekor), 5.0 - 6.9 tahun (20 ekor), dan sapi dengan umur tujuh tahun atau lebih (7 ekor). Semua sapi disinkronisasi menggunakan preparat hormon prostaglandin (PGF2 $\alpha$ ) dengan merk dagang capriglandin.Selanjutnya dilakukan pengamatan estrus dan diperoleh 39 ekor $(62 \%)$ yang memberikan respon estrus nyata terhadap sinkronisasi dengan rataan kualitas estrus 2.5. Hal ini mungkin disebabkan beberapa faktor, antara lain skor kondisi tubuh ternak yang sangat bervariasi dari 1,5-4.0 (skor penilaian 1-5).

Berdasarkan kelompok umur, kelompok sapi dengan kisaran umur 5.0-6.9 tahun menunjukkan respon estrus lebih awal yaitu 68.32 jam setelah penyuntikan, disusul kelompok sapi dengan kisaran umur 3.0-4.9 yaitu 72,68 jam dan kelompok sapi dengan kisaran umur 7 tahun atau lebih yaitu 73,22 jam. Data tersebut menunjukkan bahwa ada kecenderungan semakin tua umur sapi, maka respon estrus akibat penyuntikan hormon PGF2 $\alpha$ akan semakin lama. Walaupun hanya 62\% (39 ekor) sapi yang menunjukkan gejala estrus yang nyata, tetapi inseminasi buatan tetap dilakukan pada semua sapi resipien.Pengamatan estrus dilakukan sampai dengan 21 hari setelah kegiatan inseminasi.Sapi yang kembali estrus dalam kurun waktu setelah estrus dicatat sebagai kelompok sapi yang gagal bunting pada inseminasi pertama dan selanjutnya diinseminasi kembali.

Non return rate (NRR) merupakan alat deteksi kebuntingan berupa persentase jumlah betina yang tidak menunjukkan birahi kembali setelah di-IB dengan sexed sperm dalam observasi 21 hari setelah penginseminasian. Berdasarkan Tabel 6 . Hasil pengamatan estrus menunjukkan bahwa ada 11 ekor sapi dari 63 ekor sapi yang estrus kembali/minta kawin kembali setelah inseminasi pertama, sedangkan jumlah sapi yang tidak estrus kembali adalah 52 ekor (79\%). Sapi-sapi yang tidak menunjukkan gejala estrus setelah penyuntikan pertama dapat dikategorikan sebagai sapi yang diprediksi bunting.Hasil penelitian ini masih lebih baik dibanding penelitian (Pamungkas dkk, 2005) yang menyatakan aplikasi inseminasi semen hasil sexing pada sapi induk peranakan ongole 
didapatkan hasil NRR nya sebesar $70 \%$. Terkait dengan deteksi kebuntingan pada sapi akseptor IB hasil sexing, Susilawati (2004) melaporkan bahwa berdasarkan NRR pada 21 dan 41 hari keberhasilan kebuntingan IB hasil sexing tampak lebih rendah dibandingkan IB dengan semen beku/control.

\section{KESIMPULAN}

Berdasarkan hasil dapat pembahasan maka disimpulkan bahwa:

1. Evaluasi terhadap kualitas spermatozoa sapi Bali dalam kondisi segar menunjukkan hasil yang sesuai dengan standar untuk diproses lebih lanjut menjadi semen sexing dalam bentuk cair.

2. Kualitas spermatozoa sapi Bali hasil sexing dalam penyimpanan 20 menit, 35 menit dan 50 menit menunjukkan penurunan dari kondisi segar baik pada persentase kosentrasi, persentase motilitas, persentase spermatozoa hidup dan persentase membran plasma utuh. Namun penurunannya itu masih diatas batas normal dan layak untuk diinseminasikan pada sapi induk.

3. Aplikasi semen hasil sexing pada sapi Bali menunjukkan persentase non return rate yang baik yaitu sebesar $79 \%$.

\section{DAFTAR PUSTAKA}

Ervandi, M., T Susilawati, dan S. Wahyuningsi.2013. Pengaruh

Pengencer yang Berbeda Terhadap Kualitas Spermatozoa Sapi Hasil Sexing dengan Gradien Albumin (Putih Telur). Fakultas Peternakan Universitas Brawijaya.

Garner, D.L. dan E.S,EHafez. 1987. Spermatozoa and seminal plasma. In: Hafez ESE, Hafez B, editors. Reproduction in farm animal. 7th ed. Philadelphia (PA): Lippincott Williams and Wilkins. p. 962109.

Pamugkas, D., L. Affandhy, A. Rasyid, D.B. Wijono dan T. Susilawati.
2003. Teknologi Pemisahan Spermatozoa X dan Y Sapi Potong Skala Laboratorium. Laporan Penelitian. Loka Penelitian Sapi Potong.

Pamugkas, D., L. Affandhy, D.B. Wijono dan Hartati. 2005.Aplikasi Inseminasi Semen hasil Sexing Pada Sapi Induk Peranakan Ongole. Seminar Nasional Teknologi Peternakan dan Veteriner. Loka Penelitian Sapi Potong

Saili, T. 1999. Efektifitas penggunaan albumin sebagai medium separasi dalam upaya mengubah rasio alamiah spermatozoa pembawa kromosom $X$ dan $Y$ pada sapi.Tesis.Program Pascasarjana. Institut Pertanian Bogor

Saili, T., M.R. Toelihere, A. Boediono, dan B. Tappa. 2000. Keefektifan albumin sebagai media pemisah spermatozoa sapi pembawa kromosom X dan Y. Jurnal Hayati. 7(4):106-109.

Saili, T., A. Bain, AS. Aku, M. Rusdin dan R. Aka. 2011. Sinkronisasi estrus melalui manipulasi hormon agen luteolitik untuk meningkatkan efisiensi reproduksi Sapi Bali dan Peranakan Ongole di Sulawesi Tenggara. Agriplus 21(1):50-54

Saili, T., MR. Toelihere, A. Boediono dan B. Tappa. 2000. Keefektifan albumen sebagai media pemisah spermatozoa sapi pembawa kromosom X dan Y. Hayati7:106109

Saili, T. 1999. Efektifitas Penggunaan Albumin sebagai Medium Separasi dalam Upaya Mengubah Rasio Alamiah Spermatozoa Pembawa Kromosom X dan Y pada Sapi. Tesis. Program Pascasarjana, Institut Pertanian Bogor.

Sianturi, R.G, P. Situmorang, E. Triwulaningsih, dan D.A. Kusumaningrum. 2007. Pengaruh 
penambahan glutathione dan kolesterol pada pemisahan spermatozoa $\mathrm{X}$ dan $\mathrm{Y}$ dengan metode kolom albumin telur. Prosiding Seminar Nasional Teknologi Peternakan dan Veteriner. Bogor, 21222 Agustus 2007. Bogor.

Sianturi, R.G., P. Situmorang, E. Triwulanningsih, T. Sugiarti, dan D.A. Kusumaningrum. 2004. Pengaruh isobutil metilxantina (IMX) dan waktu pemisahan terhadap kualitas dan efektivitas pemisahan spermatozoa dengan metode kolom albumin telur. JITV. 9(4):246-251
Susilawati, T. 2011. Spermatologi. UB Press.Malang.

Susilawati, T. 2003. Tingkat Keberhasilan Inseminasi Buatan Pada Sapi peranakan Ongole Menggunakan Semen Beku Hasil Sexing dengan Gradien Kosentrasi Putih Telur. Protein, Jurnal Ilmiah dan Ilmu Peternakan dan Perikanan, JuliDesember.20 :1431-1438.

Susilawati, T., Hermanto, P. Srianto, dan E. Yuliani. 2002. Pemisahan spermatozoa $\mathrm{X}$ dan $\mathrm{Y}$ pada sapi brahman menggunakan gradien putih telur pada pengencer tris dan tris kuning telur. Jurnal Ilmu-Ilmu Hayati 14(2):176-181. 